\title{
PENGARUH PENAMBAHAN PASIR TERHADAP DAYA DUKUNG SUBGRADE JALAN
}

\author{
Yudha Fardyansah ${ }^{1,2)}$, Nurly Gofar ${ }^{2)}$ \\ 1) Dinas Perumahan Rakyat dan Kawasan Pemukiman Kota Palembang, Palembang \\ 2) Program Studi Magister Teknik Sipil, Pascasarjana Universitas Bina Darma \\ Jalan A Yani No 3 Palembang 30111
}

\begin{abstract}
The performance of flexible pavement is highly influenced by the quality of subgrade material. In Palembang, the foundation soil is usually consisted of clay which is sensitive to change in water content caused by rainfall as well as inundation. This paper presents results of laboratory study on the effect of adding sand to clay to be used as subgrade material for urban roads. California Bearing Ratio (CBR) values were used as indication of strength improvement of the subgrade in unsoaked and soaked conditions. The suitability of the stabilized soil for use as subgrade of pavement construction in response to normal and inundated conditions was further assessed through field verification using Dynamic Cone Penetrometer. Results of both laboratory and field studies indicated that addition of $21 \%$ sand by dry weight give the most improvement in terms of CBR value. In this case, the CBR unsoaked increased from $8 \%$ to $18 \%$ while the CBR soaked increased from less than 3\% to $8 \%$. Field verification showed that the CBR of compacted natural soil decreased from $8 \%$ to $2 \%$ after rainfall while the CBR of the sand stabilized soil decreased from $17 \%$ to $8 \%$. Thus the sand stabilized clay is expected to perform adequately even after subjected to rainfall and inundation.
\end{abstract}

Key Words: CBR, flexible pavement, rainfall and inundation, sand stabilized clay, subgrade.

\section{PENDAHULUAN}

Jalan merupakan satu infrastruktur penting dalam perkembangan wilayah. Infrastruktur jalan yang baik diperlukan untuk mengikat dan menghubungkan pusat-pusat kegiatan. Ditinjau dari konstruksinya, ada dua jenis perkerasan jalan yang umum digunakan yaitu perkerasan kaku (rigid pavement) dan perkerasan lentur (flexible pavement) (Saurabh, dkk. 2013).

Dalam konstruksi perkerasan kaku, semua beban jalan di tanggung oleh pelat (slab) beton sehingga daya dukung tanah dasar menjadi tidak begitu penting. Namun apabila kerusakan subgrade sudah cukup meluas, maka pelat beton akan mengalami lendutan dan kerusakan yang parah sehingga memerlukan biaya perbaikan yang tinggi. Sebaliknya untuk perkerasan lentur, subgrade jalan harus cukup kuat menahan sebaran beban dari lapisan lapisan perkerasan di atasnya. Lapisan subgrade harus memiliki stabilitas yang cukup ketika mengalami pembebanan berulang dan harus bekerja lebih baik dalam kondisi iklim yang tidak baik (Raju dkk, 2018). Konstruksi perkerasan lentur terdiri dari: a) Lapisan permukaan (aspal) b) lapisan base c) lapisan subbase dan d) tanah dasar atau subgrade (AASHTO, 2004). Dari segi kekuatan, maka tanah dasar harus memiliki nilai $\mathrm{CBR}>6$.
Bila tanah dasar tidak memenuhi persyaratan daya dukung, maka dibuat satu lapisan subgrade dari tanah yang di stabilisasi sehingga CBR gabungan antara lapisan tanah yang distabilisasi dan tanah asli mencapai nilai lebih besar daripada 6. Gambar 1 memperlihatkan konstruksi perkerasan lentur.

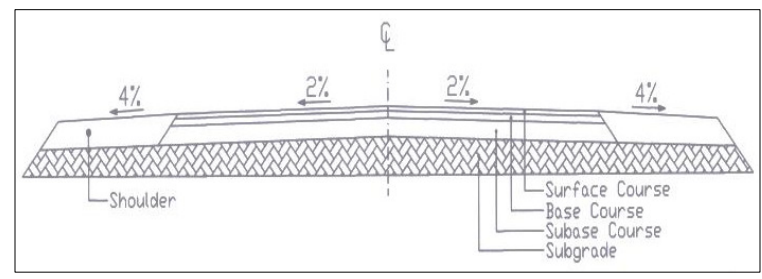

Gambar 1. Konstruksi pekerasan lentur

Di Palembang, infrastruktur jalan seringkali harus di bangun di atas tanah lempung yang memiliki daya dukung rendah. Kerusakan jalan di Palembang umumnya terjadi karena seringnya badan jalan tergenang air akibat hujan lebat atau naiknya muka air sungai. Oleh karena itu, pembangunan jalan di Palembang biasa menggunakan perkerasan kaku atau umum disebut konstruksi perkerasan beton. Terdapat beberapa kelemahan dari pekerasan kaku terutama apabila digunakan sebagai jalan dalam kota, antara lain biaya awal yang relatif lebih mahal, biaya perbaikan 
yang tinggi apabila terjadi kerusakan, bentuk permukaan yang kasar dan daya pantul yang tinggi sehingga mengurangi kenyamanan dalam mengemudi, serta tidak ramah lingkungan. Oleh karena itu perkerasan lentur merupakan pilihan yang baik untuk jalan dalam kota. Akan tetapi, perkerasan lentur harus dibangun di atas tanah yang memiliki daya dukung yang memadai. Oleh karena itu, perlu dilakukan perbaikan tanah dasar untuk memperbaiki kinerja jalan (Mohod \& Kadam, 2016). Salah satu metode perbaikan tanah yang sederhana dan ramah lingkungan adalah dengan penambahan pasir pada tanah dasar untuk membentuk lapisan subgrade.

Pasir sungai banyak terdapat di Palembang dan sekitarnya. Pasir sungai telah digunakan pada proyek reklamasi di bagian selatan kota Palembang sekitar 30 tahun yang lalu dan sampai saat ini kondisi tanah dan bangunan di atas nya nya cukup baik. Demikian pula, pasir sungai di Sumatera selatan mempunyai sifat yang cukup baik bahkan bisa digunakan sebagai pengganti pasir kuarsa untuk pengujian sand cone (Sarino \& Gofar, 2005).

Penggunaan pasir untuk memperbaiki tanah lunak sebagai subgrade telah dipelajari oleh banyak peneliti antara lain Roy (2013), Prasenda dkk. (2015), dan Simanjuntak dkk. (2017). Penelitian ini difokuskan pada peningkatan kekuatan subgade berdasarkan hasil pengujian pemadatan dan CBR di laboratorium. Dalam hal ini, dilakukan pengujian CBR tanpa rendaman. Roy (2013) melakukan penelitian mengenai kemungkinan pemakaian beberapa jenis pasir untuk menstabilisasi tanah lempung untuk digunakan sebagai lapisan subgrade. Hasil penelitian menunjukkan penambahan $15 \%$ pasir memberikan perbaikan karakteristik tanah lempung berdasarkan nilai plastisitas dan nilai CBR yang didapatkan. Terdapat peningkatan nilai CBR tanpa rendaman sebesar hampir dua kali (dari sekitar 5\% kepada 9\%) untuk setiap campuran yang diuji. Peningkatan nilai CBR ini disebabkan oleh perbaikan distribusi ukuran partikel tanah. Peningkatan nilai CBR yang cukup signifikan juga diamati oleh Simanjuntak dkk. (2017), dimana dengan penambahan $30 \%$ pasir yaitu nilai CBR tanah asli meningkat dari $7 \%$ ke pada $14 \%$. Sebaliknya, penelitian oleh Prasenda dkk. (2015), menunjukkan walaupun penambahan pasir memperbaiki sifat plastisitas tanah, tetapi peningkatan CBR yang terjadi tidak siginfikan.

Penelitian yang dilakukan dengan mempertimbangkan pengaruh perendaman terhadap tanah lempung yang distabilisasi dengan pasir vulkanik dan gipsum dilakukan oleh Putri \& Marzuko (2018). Dalam hal ini, pengujian CBR di laboratorium dilakukan dengan pemeraman selama 3 hari dan perendaman selama 4 hari. Hasilnya menunjukkan bahwa perendaman mengakibatkan penurunan nlai CBR tanah asli dari 7\% ke $1 \%$. Penambahan gypsum (4\%) dan pasir vulkanik (20\%) memberikan perbaikan nilai CBR tanpa rendaman sampai $27 \%$. Perendaman mengakibatkan pengurangan nilai CBR menjadi $15 \%$. Dengan demikian campuran ini dapat digunakan sebagai subgrade karena nilai CBR setelah rendaman $>6 \%$. Namun tidak diketahui apakah perbaikan kinerja ini disebabkan murni oleh pengaruh pasir atau lebih dipengaruhi oleh gypsum. Selanjutnya, hasil penelitian Dermawan dkk. (2017) menyimpulkan bahwa perendaman selama 4 hari hampir tidak mempengaruhi nilai CBR tanah yang distabilisasi dengan pasir.

Makalah ini memaparkan hasil penelitian laboratorium dan verifikasi lapangan terhadap pengaruh pasir terhadap plastisitas, potensi pengembangan dan nilai CBR tanah asli pada kondisi tanpa rendaman dan dengan rendaman selama 7 hari. Penelitian dilakukan terhadap jalan lokal (Jalan kelas III menurut peraturan DitJend Bina Marga, 2004) dengan tekanan gandar maximum 8 ton. Verifikasi lapangan dilakukan pada salah satu ruas jalan di kota Palembang yang pada saat ini masih dalam perbaikan yaitu ruas jalan Sukosari - Lubuk Bakung. Pengujian CBR lapangan dilakukan dengan menggunakan penguian Dynamic Cone Penetration (DCP). Penggunakan pengujian DCP untuk mengetahui kinerja subgrade juga dilakukan oleh Salgado \& Yoon (2002).

\section{METODOLOGI}

Penelitian ini menggunakan dua metodologi yaitu pengujian laboratorium dan verifkasi lapangan. Baik pengujian laboratorium maupun lapangan dilakukan mengikuti prosedur pengujian Standard Nasional Indonesia (SNI) atau ASTM. Bahan yang diteliti adalah tanah lempung yang di ambil dari ruas jalan Sukosari - Lubuk Bakung di bagian barat kota Palembang. Pasir adalah pasir sungai yang di ambil dari sungai di Palembang. Pengujian verifikasi lapangan dilakukan pada lokasi yang sama dengan lokasi pengambilan sampel tanah asli. Lokasi pengambilan sampel tanah asli dan lokasi pengujian verifikasi lapangan diperlihatkan pada Gambar 2.

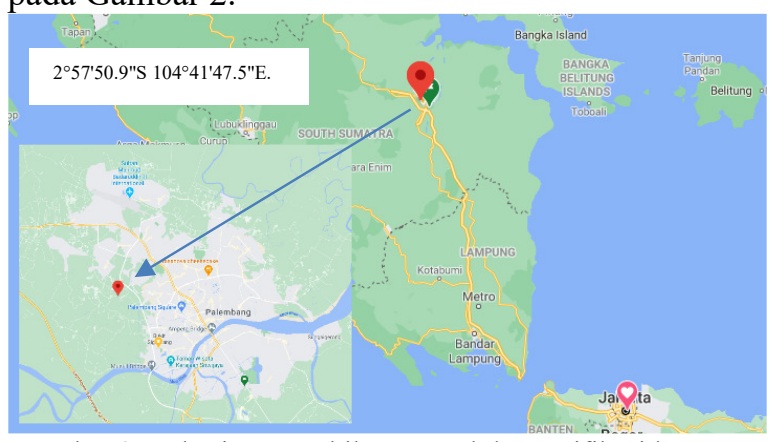

Gambar 2. Lokasi pengambilan sampel dan verifikasi lapangan 
Cantilever $\mid$ Volume: 9 Nomor: 1 Oktober 2020 ISSN: 1907-4247 (Print) $\mid$ ISSN: 2477-4863 (Online) $\mid$ Website: http://cantilever.id Yudha Fardyansah dan Nurly Gofar | Pengaruh Penambahan Pasir Terhadap Daya Dukung Subgrade Jalan

\section{Pengujian Laboratorium}

Tahap awal dari penelitian ini adalah untuk mengetahui sifat index dari tanah lempung lokal dan pasir. Dalam hal ini dilakukan pengujian berat jenis /specificgravity/Gs (SNI 1964-2008); distribusi ukuran partikel tanah (SNI 3423:2008); plastisitas tanah yang dievaluasi berdasarkan batas cair $(w L)$, batas plastis $(w P)$, dan index plastisitas $(I P)$ yang diuji mengikuti SNI-1967-2008 dan SNI 19662008. Pasir di evaluasi terhadap distribusi ukuran butiran tanah menggunakan analisis saringan (SNI 3423-2008) dan berat isi maximum dan minimum. Tanah lempung dan pasir kemudian di klasifikasikan berdasarkan AASHTO dan USCS atau ASTM D2487 (SNI 6371-2015).

Campuran lempung-pasir dipersiapkan berdasarkan berat kering. Dalam hal ini tanah lempung dicampur dengan pasir sebanyak $0 \%, 5 \%$, $10 \%, 15 \%, 20 \%, 25 \%$. Tanah asli dan setiap campuran lempung-pasir di uji terhadap batas cair dan index plastisitas untuk mengetahui pengaruh pasir terhadap plastisitas tanah. Nilai batas cair dan batas plastis juga diperlukan untuk memperkirakan variasi kadar air yang harus ditambahkan pada campuran tanah pada saat melakukan pengujian pemadatan.

Pengujian pemadatan standar Proctor dilakukan terhadap tanah asli dan setiap campuran lempungpasir mengikuti prosedur SNI 1742-2008. Lima sampel dipersiapkan dengan kadar air yang diperkirakan berdasarkan batas plastis dan batas cair. Pemadatan dilakukan terhadap sampel yang telah dimasukkan ke dalam cetakan berdiameter $104 \mathrm{~mm}$ dengan 25 pukulan pada tiga lapisan. Dalam hal ini palu pemadat dengan berat $2,5 \mathrm{~kg}$ di jatuhkan dari ketinggian $300 \mathrm{~mm}$ ke atas sampel tanah. Setelah selesai peroses pemadatan, sampel dikeluarkan, di timbang dan diukur volumenya. Kemudian pengujian kadar air dilakukan terhadap contoh yang diambil di beberapa bagian sampel. Kadar air $(w)$ ditentukan mengikuti prosedur SNI 1965-2008. Berat kering tanah ditentukan berdasarkan berat dan volume tanah serta kadar air. Berat isi kering di plot terhadap kadar air untuk menentukan berat isi kering maximum (Maximum dry density, $M D D$ ) serta kadar air optimum. Enam set kurva pemadatan didapatkan dari hasil pengujian pemadatan.

Pengujian CBR adalah salah satu metode yang paling umum digunakan untuk mengevaluasi kekuatan material sub grade tanah, sub base, dan base course untuk desain jalan raya. Dalam penelitian ini, uji CBR laboratorium dilakukan terhadap tanah asli dan setiap campuran lempungpasir yang dibuat pada kadar air optimum yang sesuai. Pengujian dilakukan mengikuti prosedur yang ditetapkan dalam SNI 1744-2012. Pengujian dilakukan pada tanah yang dipadatkan dan diperam selama 1 hari. Uji CBR yang tidak direndam (CBR unsoaked) dapat dilakukan langsung pada sampel setelah proses pemeraman. Prosedur standar menetapkan bahwa uji CBR dengan rendaman (CBR soaked) dilakukan terhadap sampel yang direndam 96 jam atau empat hari. Dalam penelitian ini perendaman dilakukan selama 7 hari untuk meniru kondisi lokal dimana sebagai respon terhadap hujan, naiknya muka air sungai dan buruknya kondisi drainase, beberapa jalan di kota Palembang bisa mengalami genangan sampai satu minggu.

Pengujian CBR dilakukan dengan mengukur tekanan yang dibutuhkan untuk menembus sampel tanah dengan plunger. Tekanan yang diukur kemudian dibagi dengan tekanan yang dibutuhkan untuk mencapai penetrasi yang sama pada bahan batuan hancur standar yang disimpan di California Department of Transportation, USA dinyatakan dalam \%. Pengukuran pengembangan tanah (swelling) dilakukan setiap hari selama proses perendaman. Gambar 3 memperlihatkan pengujian CBR dan pengukuran swelling pada pengujian CBR dengan rendaman.

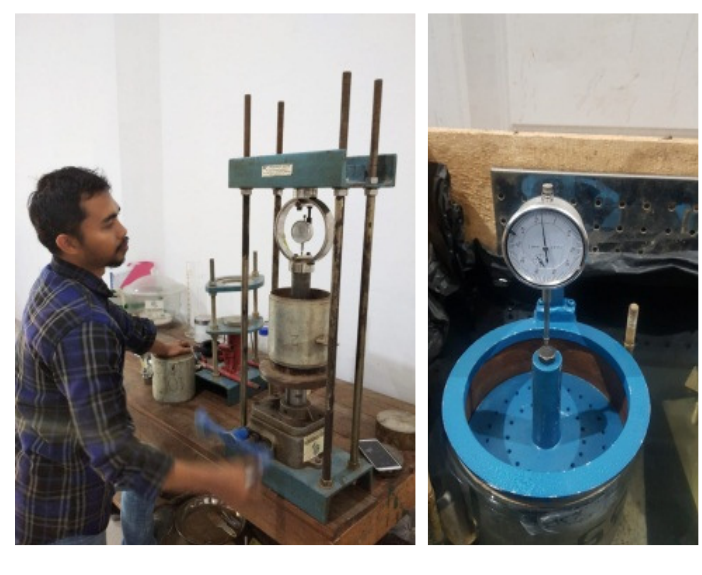

Gambar 3. Pengujian CBR laboratorium

Hasil pengujian yang didapatkan dalam penelitian ini yaitu plastisitas tanah, sifat pemadatan serta pengembangan tanah dan nilai CBR unsoaked dan CBR soaked, di analisis untuk mengetahui pengaruh penambahan pasir terhadap tanah asli. Hasil uji laboratorium juga digunakan untuk menentukan persentase pasir yang optimal untuk ditambahkan kepada tanah asli untuk digunakan sebagai subgrade jalan. Persentase optimum pasir untuk ditambahkan ke pada tanah lempung dapat diperoleh berdasarkan sifat pemadatan dan nilai CBR.

\section{Verifikasi Lapangan}

Uji verifikasi lapangan bertujuan untuk membandingkan kinerja tanah yang dicampur 
dengan $21 \%$ pasir dengan tanah asli. Dua buah petak dengan ukuran $2 \mathrm{~m} \times 2 \mathrm{~m}$ dan kedalaman $60 \mathrm{~cm}$ disiapkan untuk pengujian verifikasi lapangan (Gambar 4). Petak 1 diisi dengan tanah asli, sedangkan Petak 2 diisi dengan campuran tanah asli dan $21 \%$ pasir. Tanah pada kedua petak di padatkan dengan menggunakan vibrating tamper hingga mencapai nilai kepadatan kering $90 \%$ pada kadar air optimum. Hasil pemadatan di evaluasi dengan pengujian sand cone (SNI 2828-2011).

Pekerjaan persiapan lahan, pencampuran dan pemadatan tanah dilakukan pada 11 Juli 2020. Kemudian ke dua petak ini ditutup terpal selama dua hari untuk proses pemeraman. Evaluasi kinerja subgrade dilakukan dengan pengujian Dynamic cone penetrometer (DCP) mengikuti ASTM D6951M-2018. Pengujian DCP yang pertama dilakukan terhadap tanah yang telah dipadatkan pada tanggal 13 Juli 2020

Kemudian terpal dibuka dan tanah dibiarkan terekspos terhadap cuaca selama 7 hari. Berhubung penelitian dilakukan di musim kemarau, maka ke dua petak disiram dengan air sampai terjadi genangan. Air dibiarkan meresap kedalam tanah dan tanah dalam petak dibiarkan selama 7 hari, kemudian kembali dilakukan pengujian DCP pada tanggal 20 Juli 2020.

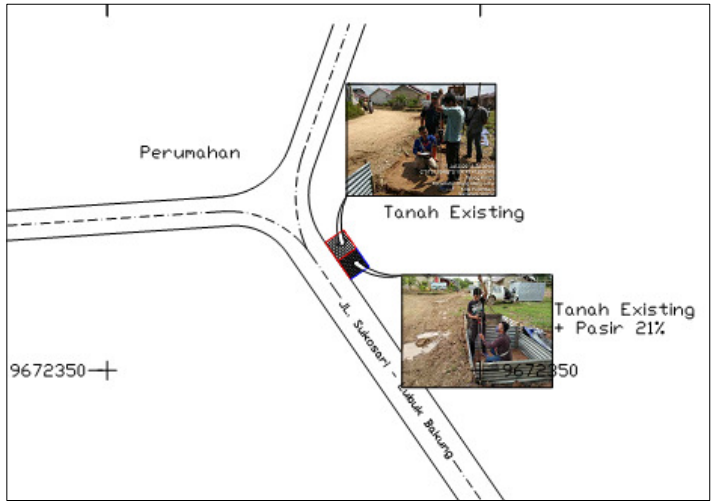

Gambar 4. Tampak atas plot pengujian verifikasi lapangan

\section{HASIL DAN PEMBAHASAN}

Hasil pengujian berkaitan dengan sifat bahan yang digunakan dalam penelitian ini dirangkum dalam Tabel 1 sedangkan distribusi ukuran butir dari tanah asli dan pasir ditunjukkan pada Gambar 5. Berdasarkan hasi pengujian saringan basah, tanah asli mengandung lebih dari $50 \%$ bahan yang lolos saringan No 200. Dengan batas cair di atas 50\% dan indeks plastisitas 25 , tanah tersebut diklasifikasikan sebagai Highly Plastic Clay $(\mathrm{CH})$ berdasarkan ASTM D2487. Menurut AASHTO, tanah ini diklasifikasikan sebagai A-7-5 sehingga tanah tidak sesuai digunakan sebagai subgrade jalan dan harus diperbaiki sifat sifatnya. Pasir tergolong pasir bersih dengan kandungan lempung hanya sekitar 3.46\%. Dengan koefisien keseragaman $(\mathrm{Cu})$ 3,3 pasir dapat diklasifikasikan sebagai SP (pasir bergradasi buruk) menurut ASTM D2487. Sedangkan untuk klasifikasi AASHTO, pasir diklasifikasikan sebagai A-1-a.

Tabel 1. Sifat tanah yang digunakan dalam penelitian

\begin{tabular}{lcc}
\hline & Lempung & Pasir \\
\hline Berat jenis (Gs) & 2,61 & 2,70 \\
Kadar Lempung (\%) & 92,64 & 3,46 \\
Batas cair $w L(\%)$ & 55,42 & - \\
Batas plastis $w P(\%)$ & 30,22 & - \\
Indeks plastisitas $I P(\%)$ & 25,20 & - \\
Klasifikasi USCS & $\mathrm{CH}$ & SP \\
Klasifikasi AASHTO & $\mathrm{A}-7-5$ & A-1-a \\
Barat isi $(\rho)$ g/cm ${ }^{3}$ & 1,80 & 1,56 (padat) \\
& 24,99 & 1,32 (longgar) \\
Kadar air awal $(\%)$ & & 3,52 \\
\hline
\end{tabular}

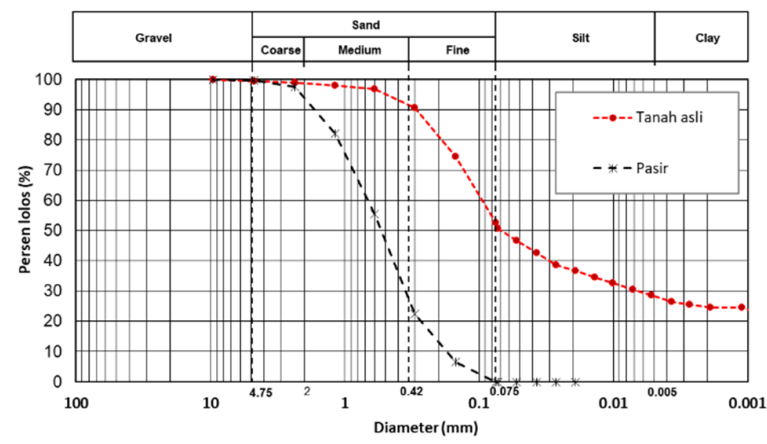

Gambar 5. Distribusi ukuran butiran tanah

Tanah asli dicampur dengan pasir $0 \%, 5 \%, 10 \%$, $15 \%, 20 \%, 25 \%$ berdasarkan berat kering. Setiap campuran diuji batas cair dan batas plastis untuk mengetahui pengaruh penambahan pasir terhadap plastisitas lempung. Gambar 6 menunjukkan pengaruh pasir terhadap plastisitas tanah. Seperti yang ditunjukkan pada gambar, efek penanmbahan pasir cukup signifikan hingga $20 \%$ tetapi ada pengurangan batas cair pada penambahan $25 \%$ pasir. Hal ini disebabkan oleh pengurangan mineral lempung dalam campuran yang mengakibatkan berkurangnya kemampuan mengikat air.

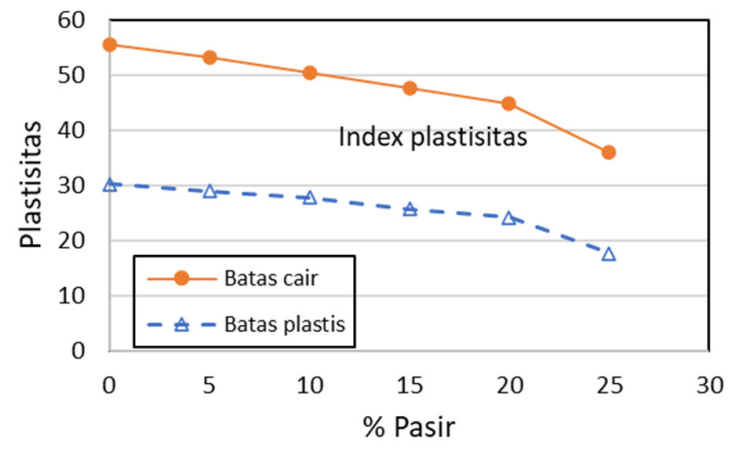

Gambar 6 Pengaruh penambahan pasir terhadap plastisitas tanah 
Cantilever $\mid$ Volume: 9 Nomor: 1 Oktober 2020 ISSN: 1907-4247 (Print) $\mid$ ISSN: 2477-4863 (Online) $\mid$ Website: http://cantilever.id Yudha Fardyansah dan Nurly Gofar | Pengaruh Penambahan Pasir Terhadap Daya Dukung Subgrade Jalan

Nilai batas cair dan batas plastis juga diperlukan untuk memperkirakan variasi kadar air untuk uji pemadatan. Hasil uji pemadatan standar Proctor menunjukkan adanya peningkatan berat jenis kering maksimum dan penurunan kadar air optimum. Gambar 7 menunjukkan variasi berat jenis kering maksimum dan kadar air optimum campuran tanah dengan persentase pasir. Kedua kurva berpotongan dengan penambahan pasir $21 \%$. Informasi ini akan digunakan dalam persiapan tanah untuk pengujian verifikasi di lapangan.

\section{Pengaruh pasir terhadap nilai CBR}

Uji CBR tanpa dan dengan rendaman dilakukan di laboratorium pada tanah asli dan 5 campuran lempung-pasir. Gambar 8 menunjukkan pengaruh penambahan pasir terhadap nilai CBR tanpa rendaman dan dengan rendaman. Uji CBR dengan rendaman dilakukan pada sampel yang diperam selama 1 hari kemudian direndam selama 7 hari. Terjadi peningkatan nilai CBR sampai dengan penambahan pasir sampai dengan $20 \%$ tetapi CBR menurun seiring dengan penambahan jumlah pasir menjadi 25\%. Hal ini dapat disebabkan oleh penurunan kohesi tanah akibat berkurangnya mineral lempung di dalam tanah. Nilai CBR maksimum (baik yang direndam maupun tidak) dicapai pada $20 \%$ pasir, tetapi garis lengkung menunjukkan bahwa persentase pasir yang optimal sedikit lebih tinggi dari 20\%. Tabel 2 memperlihatkan ringkasan hasil pengujian CBR yang dilkasanakan di laboratorium.

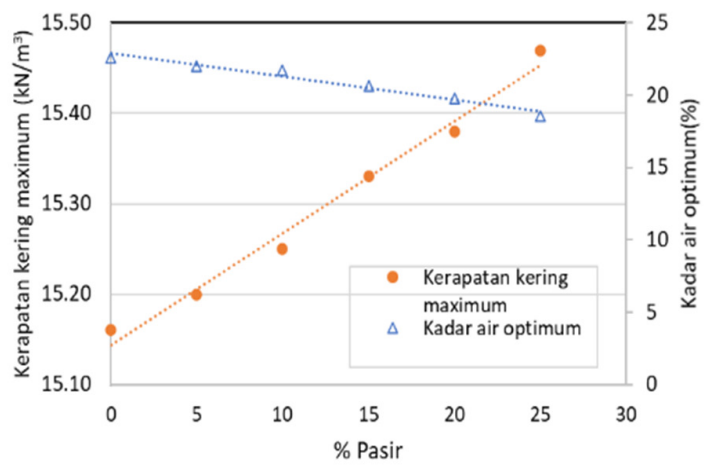

Gambar 7. Pengaruh penambahan pasir terhadap sifat kepadatan tanah

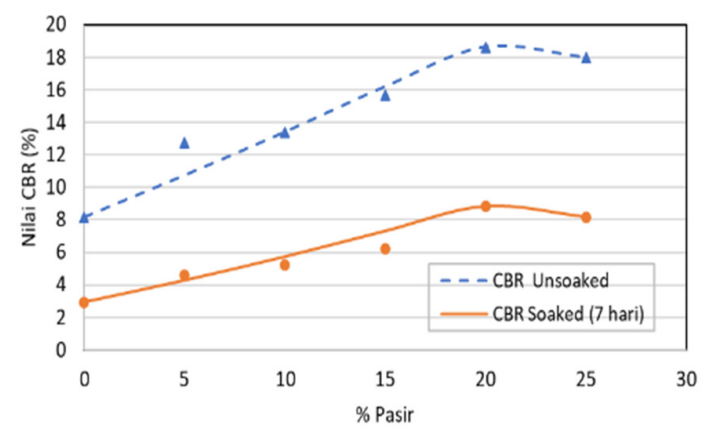

Gambar 8 Pengaruh penambahan pasir terhadap nilai CBR
Table 2. Hasil pengujian CBR di laboratorium

\begin{tabular}{lcc}
\hline & $\begin{array}{c}\text { Tanah asli } \\
\text { (Lempung) }\end{array}$ & $\begin{array}{c}\text { Campuran } \\
\text { Lempung + Pasir }\end{array}$ \\
\hline CBR unsoaked & $8 \%$ & $18 \%$ \\
CBR soaked (7 hari) & $2 \%$ & $8 \%$ \\
\hline
\end{tabular}

\section{Pengaruh rendaman terhadap nilai CBR}

Pengembangan sampel diamati setiap hari selama periode perendaman. Gambar 9 menunjukkan plot pembacaan dial dengan lama perendaman pada tanah asli dan capuran lempungpasir. Gambar tersebut menunjukkan bahwa untuk tanah asli, hubungan antara pengembangan (swelling) dan lama perendaman adalah eksponensial sedangkan untuk campuran lempungpasir, hubungannya berangsur menjadi linier. Kemiringan garis menurun dari 39 (5\% pasir) menjadi 17 (25\% pasir) yang menunjukkan bahwa pengaruh genangan terhadap swelling semakin berkurang dengan bertambahnya jumlah pasir yang ditambahkan ke tanah asli.

Variasi indeks pengembangan dengan persentase pasir ditunjukkan pada Gambar 10. Indeks pengembangan menurun secara linier dari 4,2\% (tanah alami) menjadi 1,3\% (25\% pasir).

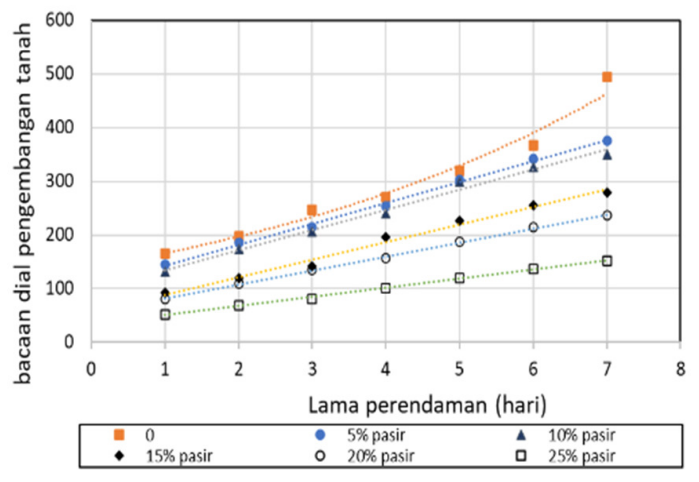

Gambar 9. Pengaruh penambahan pasir terhadap potensi pengembangan tanah

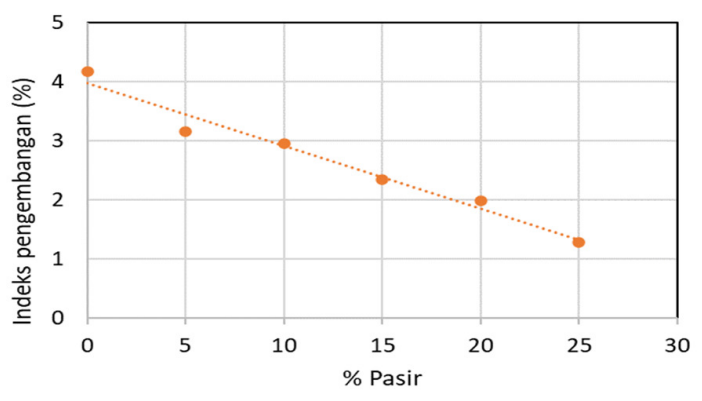

Gambar 10. Pengaruh penambahan pasir terhadap indeks pengembangan tanah

\section{Hasil pengujian verifikasi lapangan}

Pengujian DCP terhadap tanah yang telah dipadatkan dilakukan pada tanggal 13 Juli 2020. Hasil pengujian menunjukkan bahwa nilai CBR rata rata tanah asli sebesar $8 \%$ sedangkan nilai CBR untuk campuran tanah dan $21 \%$ pasir sebesar $17 \%$. 
Hasil pengujian DCP yang dilakukan pada tanggal 20 Juli 2020 yaitu terhadap tanah yang telah mengalami penggenangan air menunjukkan bahwa nilai CBR tanah asli turun menjadi $2 \%$ sedangkan nilai CBR campuran tanah-pasir turun menjadi $8 \%$. Tabel 3 memperlihatkan ringkasan hasil pengujian CBR di lapangan.

Table 3. Hasil pengujian CBR (verifikasi lapangan)

\begin{tabular}{lcc}
\hline \multirow{2}{*}{ Waktu } & \multicolumn{2}{c}{ CBR } \\
\cline { 2 - 3 } & $\begin{array}{c}\text { Plot 1 Tanah asli } \\
\text { (Lempung) }\end{array}$ & $\begin{array}{c}\text { Plot 2 Lempung } \\
+\mathbf{2 1 \%} \text { Pasir }\end{array}$ \\
\hline 13 Juli 2020 & $8 \%$ & $17 \%$ \\
20 Juli 2020 & $2 \%$ & $8 \%$ \\
\hline
\end{tabular}

Hasil pengujian lapangan ini (Tabel 3) sebanding dengan nilai CBR tanpa dan dengan rendaman yang diperoleh dari uji laboratorium (Tabel 2). Hasil penelitian ini mendukung hasil penelitian sebelumnya yang dilakukan oleh Roy (2013), Simanjuntak dkk. (2018) dimana terdapat peningkatan nilai CBR unsoaked akibat penambahan pasir. Selanjutnya penambahan pasir mengurangi pengaruh rendaman terhadap nilai CBR (Putri dan Marzuko, 2018) serta Dermawan dkk (2017).

Genangan menyebabkan kondisi permukaan tanah dasar yang tidak diolah menjadi berlumpur sedangkan permukaan tanah dasar yang diolah dengan pasir hanya sedikit terpengaruh.

\section{KESIMPULAN}

Pengaruh penambahan pasir terhadap kinerja tanah asli untuk subgrade konstruksi jalan diamati dalam penelitian ini. Hasil pengujian laboratorium menunjukkan adanya penurunan plastisitas tanah dan indeks pengembangan (swell) seiring dengan bertambahnya jumlah pasir. Penambahan pasir menyebabkan tanah menjadi kurang responsif terhadap keberadaan air. Analisis lebih lanjut menunjukkan bahwa pengembangan tanah asli meningkat secara eksponential pada tanah asli, sedangkan untuk campuran lempung-pasir peningkatan terhadap waktu adalah linier.

Uji pemadatan menunjukkan bahwa penambahan jumlah pasir juga meningkatkan berat jenis kering maksimum dan menurunkan kadar air optimum. Baik CBR yang tidak direndam maupun yang direndam meningkat seiring dengan bertambahnya jumlah pasir. Semua pengujian menunjukkan bahwa terdapat kondisi optimum dimana penambahan jumlah pasir lebih lanjut tidak menyebabkan peningkatan kekuatan. Oleh karena itu, kandungan pasir 21\% dipilih untuk verifikasi lapangan.

Hasil studi lapangan menunjukkan nilai CBR yang lebih tinggi diperoleh untuk campuran pasir- lempung. Tanah dasar yang terbuat dari campuran pasir-lempung menunjukkan respon yang kurang terhadap pembasahan dan penggenangan. Pengujian DCP menujukkan nilai CBR tanah asli turun dari $8 \%$ kepada $2 \%$ sedangkan untuk campuran lempung - pasir dengan kadar $21 \%$ nilai CBR turun dari $17 \%$ kepada $8 \%$. Dengan demikian, walaupun ter ekspos hujan dan genangan selama 7 hari, campuran ini masih bisa digunakan sebagai subgrade jalan.

\section{UCAPAN TERIMA KASIH}

Penulis mengucapkan terimakasih kepada dosen dan staff Program Magister Teknik Sipil Universitas Bina Darma serta Reviewer dan Editor yang telah membantu menyempurnakan manuskrip ini.

\section{REFERENSI}

AASHTO (2004). Standard specifications for Transportation materials and Methods of Sampling and Testing. USA: American Association of State Highway Officials.

ASTM D6951 / D6951M-18. (2018). Standard Test Method for Use of the Dynamic Cone Penetrometer in Shallow Pavement Applications. West Conshohocken: ASTM International.

Dermawan, A., Puri, A., \& Mildawati, R. (2017). Pengaruh Perendaman Terhadap Kuat Dukung Tanah Terstabilisasi Pasir. Prosiding Konferensi Nasional Teknik Sipil dan Perencanaan (KN-TSP) 2017, 63 - 68.

DitJend Bina Marga. (2004). Spesifikasi Teknis Jalan. Jakarta: DitJend Bina Marga.

Mohod, M. V. \& Kadam, K. N. (2016). A Comparative Study on Rigid and Flexible Pavement: A Review. IOSR Journal of Mechanical and Civil Engineering. 13(3), 8488.

Prasenda, C., Setyanto, \& Iswan. (2015). Pengaruh Penambahan Pasir Terhadap Tingkat Kepadatan dan Daya Dukung Tanah Lempung Lunak. JRSDD, 3(1), 91 - 102.

Putri, A. Y. \& Marzuko, A. (2018). Stabilisasi Tanah Lempung Dengan Campuran Pasir Vulkanik Merapi Dan Gipsum Untuk Subgrade Perkerasan Lentur Jalan.. Universitas Islam Indonesia: Yogyakarta.

Raju, S., Kolathayar, S., \& Sharma, A. (2018). Strength Behavior of Subgrade Soil Mixed with Sand Manufacturing Dust and Fiber. Journal of GeoEngineering, 13(2), 79-84.

Roy, T. P. (2013). Influence of Sand on Strength Characteristics of Cohesive Soil for Using as Subgrade of Road. Procedia - Social and Behavioral Sciences, 104, 218 224.

Salgado, R. \& Yoon, S. M. (2002) Dynamic Cone Penetration Test (DCPT) for Subgrade Assessment, Final Report (Publication No: FHWA/IN/JTRP-2002/30), West Lafayette: INDOT Research.

Sarino \& Gofar, N. (2005). Use of Local Sand for Standard Material for Sand Cone Test. Jurnal Teknik Sipil Sriwijaya. 1(1), 28-33.

Saurabh, J., Joshi, Y. P., \& Goliya, S. S. (2013). Design of Rigid and Flexible Pavements by Various Methods \& Their Cost Analysis of Each Method, Int. Journal of Engineering Research and Applications, 3(5), 119-123.

Simanjuntak, M. R. A., Lubis, K., \& Rangkuti, N. M. (2017) Stabilisasi Tanah Lempung dengan Campuran Pasir Pantai terhadap Nilai CBR, JCEBT, 1(2), 96-104. 